\title{
Pengaruh pemberian pangan antioksidan terhadap kadar malondialdehid plasma mahasiswi penyuka gorengan
}

Antioxidant foods effect on plasma-malondialdehyde level among college students who frequently consuming fried foods

\author{
Inti Makaryani*, Leily Amalia*, Novi Rizqi Ramadhani, Karina Indah Pertiwi, Desy Dwi Aprillia
}

\begin{abstract}
Background: Antioxidant elements such as vitamin C, vitamin E, lycopene, chlorophyl, polifenol, and other flavonoid existed on various foods of fruits, vegetable, tea, coffee, and others. The foods are usually consumed in our every single day. Some previous studies had shown that there were various benefits of antioxidant elements for animal and human health. However, the antioxidative effect of the antioxidant elements in combating free radicals in the body are not similar for each other. Objective: This study was aimed to analyze the effect of antioxidant foods (green grass jelly drinks, tomato juice, papaya, and black tea) on blood levels of malondialdehyde (MDA) among college students. Method: The study was designed by pre-post test control study. Subjects were divided into five groups, consisted of four intervention groups and one control group. Every group consisted 6 persons. Each subject was asked to consume one kind of antioxidant foods in a single serving size per day for 21 days. Results: All of the subjects who consumed fried foods had high MDA levels in pre-intervention. The results of this study showed that MDA level in the group of green grass jelly drink decreased significantly $(p<0.05)$. Plasma MDA levels tend to decline between pre and post intervention in the group of tomato juice, papaya, and tea, but they were not statisticaly significant $(p>0,05)$. Conclusion: The antioxidant foods which can reduce plasma MDA level were green grass jelly drink. However, tomato juice, papaya and tea can also reduce plasma MDA level, but not statistically significant.
\end{abstract}

KEY WORDS: plasma MDA level, antioxidant source food, intervention, fried foods

\begin{abstract}
ABSTRAK
Latar belakang: Zat antioksidan seperti vitamin C, vitamin E, likopen, polifenol, dan flavonoid terkandung dalam berbagai pangan seperti buah, sayuran, teh, kopi, dan lainnya. Pangan-pangan tersebut biasa dikonsumsi setiap hari. Beberapa penelitian sebelumnya menunjukkan bahwa terdapat berbagai manfaat zat antioksidan bagi kesehatan hewan dan manusia. Meskipun demikian, efek antioksidatif dari zat-zat antioksidan dalam melawan radikal bebas di tubuh tidaklah sama antara zat antioksidatif yang satu dengan yang lainnya. Tujuan: Menganalisis efek pangan antioksidan (minuman cincau hijau, jus tomat, pepaya, dan teh hitam) terhadap kadar malondialdehid (MDA) darah pada mahasiswi. Metode: Studi ini menggunakan desain pre-post test control. Subjek dibagi ke dalam 5 kelompok yang terdiri dari 4 kelompok intervensi dan 1 kelompok kontrol. Setiap kelompok terdiri dari 6 orang. Setiap subjek dalam kelompok intervensi diminta untuk mengonsumsi satu jenis pangan antioksidan sebanyak 1 takaran saji per hari selama 21 hari. Hasil: Seluruh subjek yang mengonsumsi makanan yang digoreng memiliki kadar MDA yang tinggi saat sebelum intervensi. Studi ini menunjukkan bahwa kadar MDA pada kelompok intervensi yang mengonsumsi minuman cincau hijau mengalami penurunan secara signifikan $(\mathrm{p}<0,05)$. Kadar MDA plasma pada kelompok intervensi jus tomat, pepaya, dan teh cenderung mengalami penurunan antara sebelum dan setelah intervensi, tetapi penurunan tersebut tidak signifikan secara statistik $(\mathrm{p}>0,05)$. Secara statistik tidak terdapat efek pada kelompok yang diintervensi jus tomat, papaya, dan teh terhadap kadar MDA subjek. Namun, terdapat kecenderungan penurunan kadar MDA plasma. Simpulan: Pangan antioksidan yang dapat mereduksi kadar MDA plasma adalah minuman cincau hijau. Meskipun jus tomat, pepaya, dan teh juga dapat mereduksi kadar MDA plasma tetapi hasilnya tidak signifikan secara statistik.
\end{abstract}

KATA KUNCI: MDA plasma, pangan sumber antioksidan, intervensi, makanan yang digoreng

\footnotetext{
*Korespondensi: Departemen Gizi Masyarakat, Fakultas Ekologi Manusia (FEMA), Institut Pertanian Bogor, Bogor 16680, e-mail: leilyamalia@yahoo.com; makaryani17@gmail.com
} 
Inti Makaryani, dkk: Pengaruh pemberian pangan antioksidan terhadap kadar malondialdehid plasma mahasiswi penyuka gorengan

\section{PENDAHULUAN}

Pengolahan pangan dengan cara digoreng merupakan kebiasaan yang banyak dilakukan oleh masyarakat Indonesia. Proses pengolahan yang praktis serta efek gurih yang ditimbulkan karena adanya minyak yang terserap dari makanan yang digoreng menjadikan makanan yang digoreng banyak digemari masyarakat termasuk mahasiswa. Penelitian tentang kebiasaan konsumsi jajanan gorengan di kalangan mahasiswa Institut Pertanian Bogor (IPB) menunjukkan bahwa dalam satu bulan rerata konsumsi gorengan pada mahasiswa sebesar 89,5 g/hari atau sekitar 2 potong per hari dengan total minyak terserap 14,6 g/hari. Mahasiswa umumnya menyukai gorengan karena sifatnya yang mengenyangkan dan harganya yang murah (1).

Gorengan umumnya digoreng dengan metode deep frying yaitu seluruh makanan terendam minyak sehingga makanan menjadi renyah (crispy). Pada proses penggorengan dengan metode deep frying, terjadi berbagai reaksi kimia seperti hidrolisis, oksidasi, siklisasi, dan polimerisasi minyak (2). Penelitian tentang pemanasan berulang dari minyak kelapa sawit menunjukkan bahwa selama penggorengan akan terbentuk senyawa radikal bebas (3). Penelitian pada beberapa jenis minyak sayur juga menunjukkan bahwa pemanasan secara berulang menghasilkan kadar senyawa toksik yang lebih tinggi pada minyak kelapa sawit (4). Radikal bebas yang terkandung pada minyak yang digunakan untuk menggoreng akan terserap pada makanan yang digoreng. Jika makanan tersebut dikonsumsi, maka radikal bebas juga akan dikonsumsi dan masuk ke dalam tubuh. Radikal bebas tersebut kemudian berikatan dengan asam lemak tidak jenuh yang banyak menyusun membran sel tubuh. Radikal bebas merusak lipid dan membentuk peroksida lipid sehingga menghasilkan malondialdehid (MDA).

Sifat oksidatif radikal bebas dapat dihentikan oleh antioksidan. Beberapa penelitian menunjukkan bahwa antioksidan dapat menurunkan kadar MDA darah. Penelitian pada mahasiswa Institut Pertanian Bogor (IPB) menunjukkan bahwa pemberian suplemen vitamin $\mathrm{C}$, vitamin $\mathrm{E}$, dan multivitamin-mineral selama seminggu dapat menurunkan kadar MDA plasma secara signifikan (5). Penelitian pada subjek setelah aktivitas aerobik membuktikan pemberian kombinasi vitamin $\mathrm{C}$, bioflavonoid, dan buah tomat dapat menurunkan kadar MDA darah secara signifikan (6). Selain itu, tikus yang diinduksi aloksan dan diberikan teh hitam selama dua minggu memiliki kadar MDA dalam organ (pankreas, jantung, ginjal, dan hati) yang lebih rendah dibandingkan kelompok tikus dengan aloksan saja (7).

Beberapa jenis zat yang telah terbukti memiliki sifat antioksidan diantaranya adalah vitamin C, klorofil, likopen, polifenol, flavonoid, dan vitamin E. Zat-zat tersebut terdapat pada beragam jenis bahan pangan yang biasa dikonsumsi sehari-hari, seperti buah-buahan, sayuran, pangan penyegar (teh, kopi, kola), dan lainnya. Dengan demikian, tanpa disadari dengan mengonsumsi bahan-bahan pangan tersebut dapat memberikan manfaat antioksidatif dalam tubuh. Meskipun demikian, daya antioksidatif dari masing-masing zat antioksidan tidaklah sama. Jenis dan kadar zat yang terkandung dalam bahan pangan akan mempengaruhi kemampuan antioksidan dalam menangkal radikal bebas.

Berdasarkan pertimbangan di atas, secara umum penelitian ini bertujuan untuk menganalisis dan membandingkan efektivitas sifat antioksidatif dari beragam bahan pangan yang mengandung antioksidan yang biasa dikonsumsi sehari-hari, yaitu minuman cincau hijau, jus tomat, pepaya, dan teh tawar. Sifat antioksidatif diukur dengan kejadian penurunan kadar MDA darah pada mahasiswi penyuka gorengan.

\section{BAHAN DAN METODE}

Penelitian ini merupakan experimental study dengan pre-post test control design dan dilaksanakan pada bulan Agustus-Desember 2013 di Kampus IPB Darmaga. Penelitian menggunakan rancangan acak lengkap dengan satu faktor yaitu pemberian hanya satu jenis pangan antioksidan pada setiap subjek kelompok perlakuan (minuman cincau hijau, jus tomat, pepaya, atau teh tawar) dan kelompok kontrol. Penelitian telah mendapat sertifikat dari Komisi Etik Fakultas Kesehatan Masyarakat, Universitas Diponegoro, Semarang. Pembuatan dan pemberian pangan intervensi dilakukan di Laboratorium Pengolahan Pangan, Departemen Gizi Masyarakat, IPB; analisis aktivitas antioksidan pangan intervensi dilakukan di Laboratorium Pusat Antar 
Universitas (PAU), Departemen Ilmu Teknologi Pangan, IPB dan Laboratorium Analisis Zat Gizi, Departemen Gizi Masyarakat, IPB; analisis kadar MDA darah dilakukan di Laboratorium Biokimia, Departemen Gizi Masyarakat, IPB.

Subjek dibagi ke dalam lima kelompok berdasarkan pangan intervensi yaitu 1) minuman cincau hijau; 2) jus tomat; 3) pepaya; 4) teh tawar; dan 5) kontrol. Jumlah subjek ditetapkan berdasarkan rumus $(\mathrm{t}-1)(\mathrm{r}-1) \geq 15$ dengan $\mathrm{t}$ (banyaknya kelompok) sebesar 5, maka diperoleh r (subjek minimal) sebesar 5 orang. Dengan prediksi drop out $15 \%$ maka jumlah subjek yang diperlukan adalah 6 orang setiap kelompok. Pemilihan subjek dilakukan dengan cara menyebar kuesioner terhadap 64 mahasiswi IPB atau sekitar dua kali lipat dari jumlah subjek yang diperlukan. Kuesioner berisi pertanyaan singkat tentang kebiasaan mengonsumsi gorengan dengan metode food frequency questionnaire (FFQ) dan preferensi terhadap pangan sumber antioksidan yang akan dintervensikan. Penyebaran kuesioner dilakukan secara purposif yaitu dilakukan pada calon subjek yang memenuhi kriteria inklusi yaitu sehat; berstatus gizi normal (indeks massa tubuh $18,5-25 \mathrm{~kg} / \mathrm{m}^{2}$ ); berusia $19-22$ tahun; biasa mengonsumsi gorengan; tidak sedang mengonsumsi suplemen dan obat; serta bersedia mengisi informed consent sebagai bentuk kesepakatan antara peneliti dengan subjek untuk bersedia berpartisipasi hingga akhir penelitian. Kriteria eksklusi subjek adalah menderita sakit kronis atau parah dalam satu bulan terakhir; memiliki riwayat penyakit keluarga; dan mengonsumsi obat.

Kebiasaan konsumsi gorengan dari 64 calon subjek tersebut kemudian diurutkan berdasarkan frekuensi konsumsi gorengan tertinggi hingga terendah. Berdasarkan urutan tersebut, dipilih 30 calon subjek dengan frekuensi konsumsi gorengan tertinggi untuk menjadi subjek penelitian. Penetapan subjek dalam pengelompokan intervensi dilakukan berdasarkan preferensi subjek terhadap pangan antioksidan. Dalam rentang waktu penelitian, 5 subjek drop out sehingga jumlah subjek pada akhir penelitian adalah 25 orang yaitu 5 subjek pada setiap kelompok.

Bahan yang digunakan terdiri atas pangan intervensi, darah subjek, dan bahan kimia untuk analisis. Bahan-bahan dalam pangan intervensi terdiri dari cincau hijau; gula merah; gula pasir; air; tomat buah warna merah; pepaya (jenis Calina); dan teh celup. Bahan kimia untuk analisis aktivitas antioksidan antara lain methanol; heksana teknis; dan 2,2-diphenyl-1-picrylhydrazyl (DPPH). Bahan yang digunakan untuk analisis MDA darah adalah pereaksi trichloroacetic acid (TCA); thiobarbituric acid (TBA); larutan $\mathrm{HCl} 1 \mathrm{~N}$; dan larutan tetraetoksipropan (TEP). Peralatan yang digunakan untuk pembuatan pangan intervensi adalah blender, timbangan digital, kompor gas, dan peralatan masak lainnya. Pengambilan darah subjek menggunakan jarum suntik $23 \mathrm{G}$, spuit $5 \mathrm{ml}$, sensi gloves, vacutainer dengan ethylenediaminetetraacetic acid (EDTA) $3 \mathrm{ml}$, tourniquet, dan cool box. Pemisahan plasma darah menggunakan sentrifuge, pipet mikro, dan microtube. Analisis aktivitas antioksidan menggunakan alat freeze dryer, vortex, rotary evaporator, dan peralatan lain. Analisis MDA menggunakan hot plate magnetic stirrer, pipet mikro 100 $\mu \mathrm{L}$ dan $1000 \mu \mathrm{L}$, serta spektrofotometer.

Pangan intervensi dibuat dan disiapkan terlebih dahulu di Laboratorium Pengolahan Pangan, Departemen Gizi Masyarakat, IPB. Pangan intervensi diberikan kepada masing-masing subjek sejumlah satu takaran saji. Intervensi dilakukan setiap hari selama 21 hari berturutturut termasuk pada hari libur. Setiap waktu intervensi, subjek diminta untuk mengonsumsi pangan intervensi di hadapan peneliti untuk memastikan bahan pangan intervensi benar-benar dikonsumsi subjek. Ukuran satu takaran saji menyesuaikan dengan ukuran pangan yang biasa dikonsumsi sehari-hari dalam setiap kali makan, yaitu 1) minuman cincau hijau diberikan dalam bentuk gel cincau hijau (162 g) yang ditambahkan gula cair (14 g); 2) jus tomat dibuat dengan cara menghancurkan dan mencampur tomat buah (190 g), gula pasir (20 g), dan air (100 ml) dengan menggunakan blender; 3) pepaya disajikan dalam bentuk 1 potong sedang (100 g); dan 4) teh tawar dibuat dengan menyeduh 1 kantung teh celup (2 g) dalam $200 \mathrm{ml}$ air panas dan diaduk selama 1 menit.

Pengambilan darah subjek dilakukan dua kali yaitu sebelum dan setelah intervensi, dalam kondisi subjek telah berpuasa selama 8-10 jam dan hanya boleh mengonsumsi air putih. Darah subjek diambil melalui vena cubiti sebanyak $5 \mathrm{ml}$ oleh tenaga medis (dokter). Darah dimasukkan ke dalam tabung vacutainer yang berisi 
EDTA agar darah tidak membeku kemudian ditempatkan dalam cool box. Darah kemudian disentrifugasi pada kecepatan 3000 rpm selama 15 menit. Darah yang telah terpisah dari bagian padat darah segera dipindahkan ke dalam microtube untuk analisis MDA.

Data lain yang dikumpulkan terdiri dari data kebiasaan konsumsi makanan gorengan, konsumsi pangan sehari, aktivitas antioksidan pangan intervensi, dan kadar MDA darah subjek sebagai respon dari pemberian pangan intervensi. Berdasarkan jenisnya, makanan gorengan dalam penelitian ini dibagi ke dalam tiga kelompok yaitu sebagai makanan jajanan, makanan sepinggan, dan lauk pauk. Data tentang kebiasaan konsumsi makanan gorengan dikumpulkan dengan metode FFQ sebelum intervensi. Subjek diminta untuk mengisi sendiri kebiasaan konsumsi gorengan pada kuesioner yang telah disediakan. Data konsumsi pangan sehari dikumpulkan dengan teknik wawancara menggunakan metode food record pada setiap hari selama masa intervensi.

Data kandungan zat gizi pangan intervensi per takaran saji diperoleh dari tabel daftar komposisi bahan makanan (DKBM). Data aktivitas antioksidan diperoleh dari hasil analisis di laboratorium dengan metode DPPH menggunakan pereaksi 2,2-diphenyl-1-picrylhydrazyl dan alat spektrofotometer pada panjang gelombang 517 $\mathrm{nm}$. Persentase aktivitas antioksidan ditentukan dengan rumus sebagai berikut:

$$
\% \text { aktivitas antioksidan }=\frac{\text { absorbansi kontrol }- \text { absorbansi larutan uji }}{\text { absorbansi kontrol }} \times 100
$$

$\operatorname{AEAC}(\mathrm{mg}$ vit. $\mathrm{C} / 100 \mathrm{~g})=$

$\left[\frac{(\% \text { aktivitas antioksidan }-\mathrm{b}) / \mathrm{a}}{1000}\right] \times$ FP $\times \frac{100}{\text { berat sampel }}$

Keterangan: $\mathrm{AEAC}=$ ascorbic acid equivalent antioxidant capacity Absorbansi kontrol = absorbansi DPPH tanpa larutan sampel

Absorbansi larutan uji $=$ absorbansi hasil reaksi antara DPPH dan larutan sampel

$\mathrm{a}, \mathrm{b}=$ ada persamaan $\mathrm{y}: \mathrm{ax}+\mathrm{b}$ yang diperoleh dari kurva standar

$\mathrm{FP}=$ faktor pengenceran

Data kadar MDA darah subjek dihitung berdasarkan pengukuran peroksida lipid dengan thiobarbituric acid (TBA). Dua molekul TBA bereaksi dengan satu molekul MDA untuk menghasilkan kromofor yang menyerap panjang gelombang ( $\lambda$ ) 532 sampai $535 \mathrm{~nm}$ (8). Kadar MDA dalam darah ditentukan dengan rumus yaitu hasil bagi antara (absorbansi - b)/a dengan volume sampel.

Data konsumsi gorengan diolah untuk mendapatkan data frekuensi rerata konsumsi gorengan per hari. Selain itu, data tersebut juga diolah untuk mendapatkan data jumlah minyak terserap dan yang dikonsumsi dengan menggunakan faktor penyerapan minyak pada masingmasing jenis makanan. Data konsumsi pangan sehari yang diambil selama 21 hari masa intervensi kemudian dirata-rata untuk mendapatkan data konsumsi pangan sehari. Data rerata konsumsi tersebut kemudian diolah menggunakan DKBM untuk mendapatkan data asupan energi dan zat gizi protein, kalsium (Ca), zat besi (Fe), vitamin A, vitamin C, vitamin E per hari. Data tingkat kecukupan energi dan zat gizi diperoleh dengan membandingkan data asupan dengan angka kecukupan gizi (AKG) untuk orang sehat secara umum, yaitu menurut Widyakarya Nasional Pangan dan Gizi (WNPG 2013). Angka kecukupan gizi tersebut digunakan karena semua subjek penelitian adalah orang sehat, berstatus gizi normal, dan memiliki aktivitas sedang yang sama antar subjek (semua subjek adalah mahasiswa yang aktif dalam kegiatan perkuliahan dan praktikum yang relatif sama).

Analisis data dilakukan secara deskriptif dan inferensia. Data konsumsi pangan dan MDA dianalisis uji beda antarkelompokdengan one-way analysis of variance (ANOVA) dan uji lanjut Duncan bila terdapat perbedaan nyata di antara kelompok. Selain itu, semua data juga diuji beda antara sebelum dan selama intervensi menggunakan uji paired-samples t test.

\section{HASIL}

\section{Konsumsi gorengan}

Sebelum intervensi, subjek rata-rata mengonsumsi gorengan 2,5 kali/hari sedangkan selama intervensi 2,4 kali/hari. Tidak terdapat perbedaan signifikan konsumsi gorengan antara sebelum dan selama intervensi pada semua kelompok maupun antarkelompok $(\mathrm{p}>0,05)$. Demikian juga jumlah minyak terserap yang dikonsumsi bersamaan dengan konsumsi makanan digoreng, tidak terdapat perbedaan antara sebelum dan selama intervensi pada semua kelompok maupun antarkelompok $(\mathrm{p}>0,05)$ (Tabel 1). 
Inti Makaryani, dkk: Pengaruh pemberian pangan antioksidan terhadap kadar malondialdehid plasma mahasiswi penyuka gorengan

Tabel 1. Frekuensi konsumsi gorengan dan minyak terserap pada masing-masing kelompok

\begin{tabular}{|c|c|c|c|c|c|c|}
\hline & \multicolumn{6}{|c|}{ Kelompok } \\
\hline & $\begin{array}{c}\text { Minuman } \\
\text { cincau hijau }\end{array}$ & Jus tomat & Pepaya & Teh tawar & Kontrol & Rerata \\
\hline \multicolumn{7}{|c|}{ Frekuensi rata-rata (kali/hari) } \\
\hline Sebelum intervensi & $2^{\mathrm{a} 1}$ & $2^{\mathrm{al}}$ & $4^{\mathrm{al}}$ & $3^{\mathrm{a} 1}$ & $2^{\mathrm{a} 1}$ & 2,5 \\
\hline Selama intervensi & $2^{\mathrm{a} 1}$ & $2^{\mathrm{al}}$ & $3^{\mathrm{a} 1}$ & $3^{\mathrm{a} 1}$ & $2^{\mathrm{a} 1}$ & 2,4 \\
\hline \multicolumn{7}{|c|}{ Minyak terserap pada gorengan (g/hari) } \\
\hline \multicolumn{7}{|c|}{ Sebelum intervensi } \\
\hline Jajanan & $9,7 \pm 12,1$ & $13,1 \pm 9,3$ & $16,8 \pm 14,4$ & $13,3 \pm 4,7$ & $6,3 \pm 4,6$ & $11,8 \pm 9,7$ \\
\hline Sepinggan & $5,0 \pm 4,2$ & $3,0 \pm 3,6$ & $3,9 \pm 3,9$ & $2,8 \pm 1,9$ & $3,7 \pm 3,9$ & $3,7 \pm 3,4$ \\
\hline Lauk pauk & $6,5 \pm 6,9$ & $10,7 \pm 10,2$ & $10,9 \pm 4,9$ & $5,0 \pm 3,8$ & $11,7 \pm 11,1$ & $9,0 \pm 7,7$ \\
\hline Total & $21,3 \pm 16,3^{\mathrm{a} 1}$ & $18,6 \pm 13,0^{\mathrm{al}}$ & $31,5 \pm 18,8^{\mathrm{al}}$ & $21,1 \pm 4,1^{\mathrm{al}}$ & $21,7 \pm 14,7^{\mathrm{a} 1}$ & $22,8 \pm 13,8$ \\
\hline \multicolumn{7}{|l|}{ Selama intervensi } \\
\hline Jajanan & $7,3 \pm 3,4$ & $6,1 \pm 2,3$ & $11,6 \pm 7,6$ & $5,4 \pm 3,5$ & $8,2 \pm 3,5$ & $7,7 \pm 4,6$ \\
\hline Sepinggan & $1,8 \pm 1,8$ & $1,5 \pm 1,4$ & $2,0 \pm 1,9$ & $3,3 \pm 4,2$ & $0,9 \pm 1,3$ & $1,9 \pm 2,3$ \\
\hline Lauk pauk & $5,6 \pm 4,1$ & $4,2 \pm 3,3$ & $9,6 \pm 3,7$ & $7,0 \pm 2,2$ & $6,1 \pm 2,8$ & $6,5 \pm 3,5$ \\
\hline Total & $14,6 \pm 2,5^{\mathrm{a} 1}$ & $11,8 \pm 4,8^{\mathrm{a} l}$ & $23,1 \pm 11,7^{\mathrm{a} 1}$ & $15,7 \pm 4,9^{\mathrm{a} 1}$ & $15,2 \pm 3,6^{\mathrm{a} 1}$ & $16,1 \pm 7,0$ \\
\hline
\end{tabular}

Keterangan: ${ }^{\mathrm{a}}=$ Huruf yang sama pada baris yang sama menunjukkan tidak terdapat perbedaan nyata antarkelompok $(\mathrm{p}>0,05)$

$1=$ Angka yang sama dalam kolom yang sama menunjukkan tidak terdapat perbedaan nyata antara sebelum dan selama intervensi $(\mathrm{p}>0,05)$

\section{Asupan dan tingkat kecukupan gizi}

Asupan dan tingkat kecukupan energi, protein, $\mathrm{Ca}, \mathrm{Fe}$, serta vitamin A subjek tidak berbeda nyata antarkelompok intervensi $(p>0,05)$ tetapi terdapat perbedaan signifikan $(\mathrm{p}<0,05)$ pada asupan dan tingkat kecukupan vitamin $\mathrm{C}$ dan vitamin $\mathrm{E}$. Kelompok intervensi pepaya memiliki asupan dan tingkat kecukupan vitamin C yang berbeda dibandingkan dengan kelompok kontrol dan teh tawar. Asupan dan tingkat kecukupan vitamin $\mathrm{E}$ kelompok jus tomat berbeda signifikan dibandingkan empat kelompok lainnya (Tabel 2).

Tabel 2 juga menunjukkan bahwa tingkat kecukupan energi dan protein subjek di bawah normal karena sebagian besar subjek hanya mengonsumsi makanan sepinggan satu atau dua kali dalam sehari dan tidak disertai dengan selingan. Tingkat kecukupan $\mathrm{Ca}, \mathrm{Fe}$, dan vitamin E sebagian besar subjek adalah kurang kecuali vitamin $\mathrm{C}$ dan tidak terdapat perbedaan signifikan asupan dan tingkat kecukupan energi dan zat gizi antarkelompok $(\mathrm{p}>0,05)$. Adapun vitamin $\mathrm{C}$, ketika data dihitung dengan memperhitungkan pangan intervensi, terdapat perbedaan antara kelompok pepaya dengan kelompok teh tawar dan kontrol, tetapi ketika tidak memperhitungkan pepaya intervensi, tidak terdapat perbedaan signifikan antarkelompok. Hal ini berarti kebiasaan konsumsi pangan sehari-hari subjek (tanpa pangan intervensi) adalah relatif sama antarkelompok.

\section{Kandungan gizi dan aktivitas antioksidan pangan intervensi}

Kandungan zat gizi pangan intervensi dihitung per satu takaran saji dari jumlah yang diintervensikan pada subjek (Tabel 3). Minuman cincau hijau relatif tinggi dalam hal kandungan $\mathrm{Ca}$ dan energi dibandingkan dengan pangan intervensi lain, tetapi rendah dalam hal vitamin A dan vitamin E. Jus tomat mengandung energi dan vitamin A yang cukup tinggi dan paling tinggi dari pangan intervensi lain. Energi yang cukup tinggi pada jus tomat berasal dari gula pasir. Sementara itu, pepaya mengandung vitamin $\mathrm{C}$ dan vitamin A yang relatif lebih tinggi dibandingkan cincau hijau dan teh tawar.

Hasil uji aktivitas antioksidan dalam penelitian ini menunjukkan bahwa pangan intervensi dengan aktivitas antioksidan tertinggi dan terendah, baik per $100 \mathrm{~g}$ maupun per takaran yang disajikan selama intervensi adalah jus tomat dan minuman cincau hijau. Aktivitas antioksidan jus tomat per takaran saji (190 g) sebesar 16,82 mg AEAC. Artinya, dalam satu kali pemberian jus tomat mampu mereduksi radikal bebas DPPH setara dengan 16,82 kali kemampuan vitamin C (Tabel 3). 
Inti Makaryani, dkk: Pengaruh pemberian pangan antioksidan terhadap kadar malondialdehid plasma mahasiswi penyuka gorengan

Tabel 2. Asupan dan tingkat kecukupan energi dan zat gizi subjek menurut kelompok perlakuan

\begin{tabular}{|c|c|c|c|c|c|}
\hline \multirow[b]{2}{*}{ Zat gizi } & \multicolumn{5}{|c|}{ Kelompok } \\
\hline & $\begin{array}{c}\text { Minuman } \\
\text { cincau hijau }\end{array}$ & Jus tomat & Pepaya & Teh tawar & Kontrol \\
\hline \multicolumn{6}{|l|}{ Energi (Kcal) } \\
\hline Asupan & $1600,9 \pm 317,9^{\mathrm{a}}$ & $1839,5 \pm 340,3^{\mathrm{a}}$ & $1698,3 \pm 259,0^{\mathrm{a}}$ & $1552,0 \pm 264,8^{\mathrm{a}}$ & $1569,7 \pm 411,5^{\mathrm{a}}$ \\
\hline TK $(\%)$ & $74,6 \pm 13,1^{\mathrm{a}}$ & $83,6 \pm 21,5^{\mathrm{a}}$ & $83,6 \pm 13,5^{\mathrm{a}}$ & $67,1 \pm 10,4^{\mathrm{a}}$ & $77,6 \pm 20,5^{\mathrm{a}}$ \\
\hline \multicolumn{6}{|l|}{ Protein (g) } \\
\hline Asupan & $39,0 \pm 4,5^{\mathrm{a}}$ & $49,48 \pm 5,7^{\mathrm{a}}$ & $44,3 \pm 9,1^{\mathrm{a}}$ & $40,0 \pm 3,4^{\mathrm{a}}$ & $38,2 \pm 12,3^{\mathrm{a}}$ \\
\hline TK (\%) & $73,8 \pm 12,0^{\mathrm{a}}$ & $89,3 \pm 13,4^{\mathrm{a}}$ & $87,5 \pm 18,4^{\mathrm{a}}$ & $69,8 \pm 8,0^{\mathrm{a}}$ & $75,8 \pm 24,1^{\mathrm{a}}$ \\
\hline \multicolumn{6}{|l|}{ Kalsium (mg) } \\
\hline Asupan & $460,0 \pm 344,1^{\mathrm{a}}$ & $397,2 \pm 118,5^{a}$ & $451,1 \pm 217,8^{\mathrm{a}}$ & $292,1 \pm 120,5^{\mathrm{a}}$ & $296,3 \pm 138,2^{\mathrm{a}}$ \\
\hline TK $(\%)$ & $41,8 \pm 31,3^{\mathrm{a}}$ & $36,1 \pm 10,8^{\mathrm{a}}$ & $41,0 \pm 19,8^{\mathrm{a}}$ & $26,6 \pm 11,0^{\mathrm{a}}$ & $26,9 \pm 12,6^{\mathrm{a}}$ \\
\hline \multicolumn{6}{|l|}{$\mathrm{Fe}(\mathrm{mg})$} \\
\hline Asupan & $12,3 \pm 6,5^{\mathrm{a}}$ & $20,3 \pm 11,0^{\mathrm{a}}$ & $14,0 \pm 4,7^{\mathrm{a}}$ & $10,9 \pm 3,6^{\mathrm{a}}$ & $10,2 \pm 3,0^{\mathrm{a}}$ \\
\hline TK $(\%)$ & $47,2 \pm 25,0^{\mathrm{a}}$ & $78,0 \pm 42,3^{\mathrm{a}}$ & $53,7 \pm 18,0^{\mathrm{a}}$ & $42,1 \pm 13,8^{\mathrm{a}}$ & $39,0 \pm 11,5^{\mathrm{a}}$ \\
\hline \multicolumn{6}{|l|}{ Vitamin A (RE) } \\
\hline Asupan & $377,5 \pm 218,1^{\mathrm{a}}$ & $659,1 \pm 306,0^{\mathrm{a}}$ & $442,3 \pm 139,0^{\mathrm{a}}$ & $511,4 \pm 375,5^{\mathrm{a}}$ & $450,4 \pm 190,7^{\mathrm{a}}$ \\
\hline TK $(\%)$ & $75,5 \pm 43,6^{\mathrm{a}}$ & $131,8 \pm 61,2^{\mathrm{a}}$ & $88,5 \pm 27,8^{\mathrm{a}}$ & $102,3 \pm 75,1^{\mathrm{a}}$ & $90,1 \pm 38,1^{\mathrm{a}}$ \\
\hline \multicolumn{6}{|l|}{ Vitamin C (mg) } \\
\hline \multicolumn{6}{|l|}{ Asupan } \\
\hline (-) pangan intervensi & $54,3 \pm 69,9^{\mathrm{a}}$ & $43,8 \pm 12,6^{\mathrm{a}}$ & $24,6 \pm 13,2^{\mathrm{a}}$ & $21,5 \pm 22,6^{\mathrm{a}}$ & $30,2 \pm 16,3^{\mathrm{a}}$ \\
\hline$(+)$ pangan intervensi & $56,9 \pm 69,9^{\mathrm{ab}}$ & $62,8 \pm 12,6^{\mathrm{ab}}$ & $102,6 \pm 13,2^{\mathrm{b}}$ & $21,5 \pm 22,6^{\mathrm{a}}$ & $30,2 \pm 16,3^{\mathrm{a}}$ \\
\hline \multicolumn{6}{|l|}{ TK $(\%)$} \\
\hline (-) pangan intervensi & $72,5 \pm 93,2^{\mathrm{a}}$ & $58,4 \pm 16,8^{\mathrm{a}}$ & $32,8 \pm 17,6^{\mathrm{a}}$ & $28,7 \pm 30,1^{\mathrm{a}}$ & $40,3 \pm 21,7^{\mathrm{a}}$ \\
\hline$(+)$ pangan intervensi & $75,9 \pm 93,2^{\mathrm{ab}}$ & $83,7 \pm 16,8^{\mathrm{ab}}$ & $136,8 \pm 17,6^{b}$ & $28,7 \pm 30,1^{\text {a }}$ & $40,3 \pm 21,7^{\mathrm{a}}$ \\
\hline \multicolumn{6}{|l|}{ Vitamin E (mg) } \\
\hline Asupan & $1,4 \pm 0,6^{\mathrm{a}}$ & $4,9 \pm 2,6^{\mathrm{b}}$ & $2,9 \pm 0,8^{\mathrm{a}}$ & $1,9 \pm 0,4^{\mathrm{a}}$ & $2,2 \pm 1,4^{\mathrm{a}}$ \\
\hline TK $(\%)$ & $9,6 \pm 4,0^{\mathrm{a}}$ & $32,9 \pm 17,7^{\mathrm{b}}$ & $19,2 \pm 5,6^{\mathrm{a}}$ & $12,3 \pm 2,5^{\mathrm{a}}$ & $14,5 \pm 9,2^{\mathrm{a}}$ \\
\hline
\end{tabular}

Keterangan: ${ }^{\mathrm{ab}}=$ Huruf yang berbeda pada baris yang sama menunjukkan terdapat perbedaan nyata antar kelompok; $\mathrm{TK}=$ tingkat kecukupan; (-) tanpa pangan intervensi; $(+)$ dengan pangan intervensi; $\mathrm{RE}=$ retional equivalent

Tabel 3. Kandungan zat gizi dan aktivitas antioksidan pangan intervensi per takaran saji

\begin{tabular}{lcccc}
\hline & \multicolumn{3}{c}{ Pangan intervensi } \\
\cline { 2 - 4 } & Minuman cincau hijau & Jus tomat & Pepaya & Teh tawar \\
\hline Kandungan gizi & & & & \\
Energi (kkal) & 51,42 & 101,30 & 46,00 & 2,53 \\
Protein (g) & 0,91 & 1,90 & 0,50 & 0,37 \\
Lemak (g) & 0,15 & 0,38 & 0,00 & 0,01 \\
Karbohidrat (g) & 12,44 & 25,45 & 12,20 & 1,30 \\
Kalsium (mg) & 17,75 & 14,30 & 23,00 & 13,77 \\
Fe (mg) & 0,60 & 0,78 & 1,70 & 0,23 \\
Vitamin A (RE) & 0,00 & 171,00 & 56,00 & 0,00 \\
Vitamin C (mg) & 2,58 & 19,00 & 78,00 & 0,00 \\
Vitamin E (mg) & 0,00 & 1,03 & 0,30 & 0,00 \\
Aktivitas antioksidan & & & & \\
Per 100 g (mg AEAC) & 0,06 & 8,85 & 0,41 & 8,28 \\
Per takaran saji (mg AEAC) & 0,10 & 16,82 & 0,41 & 16,57 \\
\hline
\end{tabular}

Keterangan: $\mathrm{Fe}=$ zat besi; $\mathrm{RE}=$ retinol equivalent $; \mathrm{AEAC}=$ ascorbic acid equivalent antioxidant capacity 


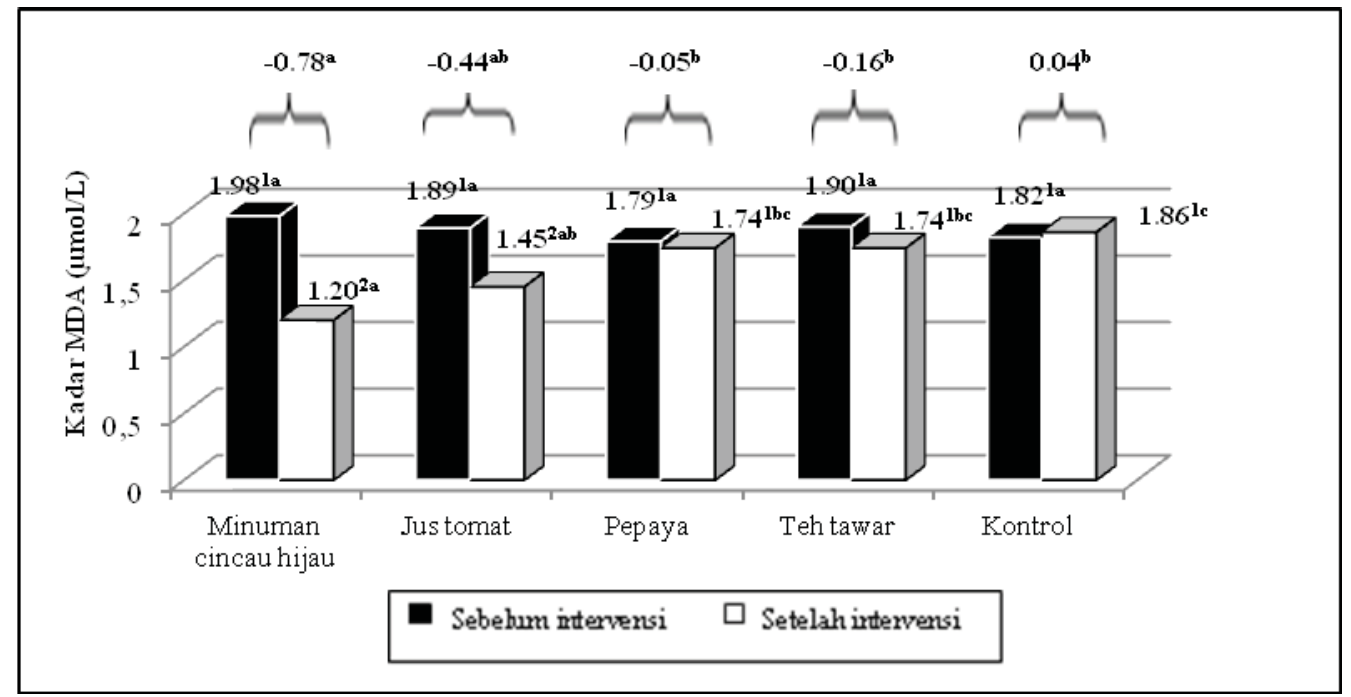

Keterangan: $\mathrm{MDA}=$ malondialdehid;

$\mathrm{abc}=$ Huruf yang berbeda pada kelompok yang berbeda dalam satu waktu masa intervensi menunjukkan perbedaan nyata antarkelompok perlakuan $(\mathrm{p}<0,05)$;

$1,2=$ Angka yang berbeda dalam satu kelompok menunjukkan perbedaan nyata antara sebelum dan setelah intervensi $(\mathrm{p}<0,05)$

\section{Gambar 1. Rata-rata kadar MDA darah subjek antarkelompok $(\mu \mathrm{mol} / \mathrm{L})$}

\section{Malondialdehid (MDA)}

Hasil penelitian ini menunjukkan adanya penurunan kadar MDA darah pada keempat kelompok perlakuan setelah intervensi dibandingkan sebelum intervensi. Sebaliknya, pada kelompok kontrol terjadi peningkatan kadar MDA darah setelah 21 hari masa intervensi meskipun tidak berbeda signifikan (dari 1,82 hingga 1,86 $\mu \mathrm{mol} / \mathrm{L})$. Penurunan kadar MDA antara sebelum dan setelah intervensi dari yang terbesar hingga yang terkecil berturut-turut terjadi pada kelompok cincau, jus tomat, teh tawar, dan pepaya (Gambar 1). Uji beda t menunjukkan bahwa kelompok cincau hijau mengalami penurunan kadar MDA yang signifikan $(\mathrm{p}<0,05)$ antara sebelum dan setelah intervensi sedangkan penurunan pada kelompok jus tomat, pepaya, dan teh tawar tidak berbeda signifikan dibandingkan dengan kelompok kontrol $(\mathrm{p}>0,05)$.

\section{BAHASAN}

Kebiasaan konsumsi makanan gorengan pada subjek penelitian ini relatif sama antarkelompok, baik sebelum maupun setelah intervensi. Hal ini berarti jumlah dan waktu konsumsi makanan gorengan tidak memiliki pengaruh terhadap hasil intervensi. Jenis makanan gorengan yang paling banyak menyerap minyak dan lebih banyak dikonsumsi oleh penyuka gorengan adalah makanan jajanan seperti bakwan, tempe goreng, dan tahu goreng dibandingkan dengan jenis makanan sepinggan (batagor, pempek, roti goreng, dan donat) dan lauk pauk (ikan goreng, ayam goreng/crispy, dan bebek goreng) baik pada saat sebelum maupun selama intervensi. Hal tersebut terjadi hampir pada semua kelompok. Hasil penelitian ini sejalan dengan hasil penelitian di Jakarta, Bogor, dan Depok tentang kandungan lipid pada makanan digoreng yang menunjukkan bahwa gorengan tempe dan bakwan yang diperoleh dari pedagang kaki lima memiliki kandungan lipid lebih tinggi dibandingkan ayam goreng (9). Jumlah minyak yang dikonsumsi subjek penelitian bisa jadi lebih tinggi dari data konsumsi minyak terserap karena jumlah minyak goreng yang dihitung hanya minyak goreng yang terserap dari makanan yang digoreng dengan metode deep frying, sedangkan minyak dari pengolahan pangan lain seperti pada makanan ditumis tidak dihitung secara khusus.

Hasil penelitian ini menunjukkan tingkat kecukupan energi dan protein subjek di bawah normal karena sebagian besar subjek hanya mengonsumsi makanan sepinggan 
satu atau dua kali dalam sehari dan tidak disertai dengan selingan. Hal ini bisa terjadi karena aktivitas kuliah dan praktikum subjek yang cukup padat sehingga waktu untuk makan menjadi cukup terbatas. Subjek memiliki tingkat kecukupan Ca yang rendah disebabkan rendahnya konsumsi pangan sumber Ca seperti susu dan produk olahannya. Demikian juga asupan Fe subjek yang kurang disebabkan oleh kurangnya jumlah konsumsi pangan sumber Fe (hati, daging, ayam, ikan). Selain itu, konsumsi biji-bijian subjek juga cukup rendah sehingga kecukupan vitamin E subjek juga rendah $(<50 \%)$. Terdapat perbedaan hasil statistik yang signifikan pada tingkat kecukupan vitamin $\mathrm{C}$ pada kelompok intervensi pepaya dibandingkan dengan keempat kelompok lain. Hasil penelitian di Hawaii Amerika menunjukkan bahwa rerata kandungan asam askorbat pada buah pepaya dengan berbagai varietas sebesar 51,2 mg/100 g, lebih tinggi dibandingkan kandungan vitamin $\mathrm{C}$ pada buah pisang yang hanya $12,7 \mathrm{mg} / \mathrm{kg}(10)$.

Lebih lanjut, aktivitas antioksidan yang diukur dalam penelitian ini adalah sifat antioksidatif pangan intervensi dibandingkan dengan sifat antioksidatif vitamin C. Sementara itu, pangan intervensi cincau hijau, jus tomat, pepaya, dan teh tawar memiliki beberapa kandungan zat aktif antioksidan lain seperti klorofil, flavonoid, dan polifenol yang mungkin memiliki sifat antioksidatif yang tidak sama dengan vitamin C. Hal ini bisa menjadi penyebab ketidaksetaraan antara jumlah antioksidan pada bahan pangan intervensi dan dampak antioksidatif dari pangan intervensi tersebut.

Antioksidan utama yang terkandung pada daun cincau hijau terutama adalah klorofil dan flavonoid. Hasil penelitian di Bogor menunjukkan bahwa daun cincau hijau Premna oblongifolia Merr. mengandung klorofil sebanyak 1708,8 mg/kg, lebih tinggi dibandingkan daun pegagan, daun katuk, dan daun murbei (11). Penelitian tentang mekanisme aktivitas antitumor menunjukkan bahwa daun cincau hijau mengandung antioksidan lain selain klorofil yaitu flavonoid (12). Penelitian di Portugal pada tahun 2012 menyatakan bahwa jenis antioksidan pada tomat dengan kandungan tertinggi hingga terendah adalah polifenol, likopen, dan tokoferol (13). Penelitian lain di Taiwan menunjukkan bahwa polifenol memberikan kontribusi terbesar dalam aktifitas antioksidan, baik sebagai antiradikal (anti radical power) maupun penghambatan peroksidasi lipid (inhibition of lipid peroxidation) pada buah tomat (14).

Pepaya memiliki antioksidan golongan vitamin (A, C, dan E) serta senyawa karotenoid (terutama betakaroten). Karoten pada pepaya lebih banyak (karoten total $2740 \mu \mathrm{m}$ ) dibandingkan dengan buah-buahan lain seperti apel dan jambu (15). Pepaya yang digunakan dalam penelitian ini adalah pepaya yang matang dengan pertimbangan memiliki kandungan antioksidan vitamin C yang lebih tinggi dibandingkan pepaya yang setengah matang. Kematangan buah pepaya dapat dilihat dari warna kulit luar yang mulai berwarna kuning atau oranye, daging buah yang lebih melunak ketika ditekan disebabkan adanya pemutusan polimer karbohidrat (terutama hemiselulosa), warna daging buah yang cerah, dan rasa yang manis disebabkan adanya depolimerisasi karbohidrat komplek sehingga menimbulkan akumulasi sukrosa (16). Penelitian di Nigeria yang membandingkan tingkat kematangan pada pepaya dengan 3 varietas berbeda menunjukkan bahwa buah pepaya yang matang memiliki kandungan vitamin $\mathrm{C}$ yang lebih tinggi dibandingkan dengan pepaya yang setengah matang dan pepaya mentah pada ketiga varietas tersebut (17). Sementara itu, teh celup yang digunakan dalam penelitian ini termasuk ke dalam golongan teh hitam. Teh hitam dibuat dengan memanfaatkan proses oksidasi pada daun melalui rangkaian proses enzimatik (18). Teh hitam memiliki komponen antioksidan theaflavin, thearubigin, dan senyawa polifenol (19).

Lebih lanjut, MDA dalam tubuh terbentuk sebagai akibat dari kondisi stres oksidatif yaitu ketidakseimbangan antara pembentukan reactive oxygen species (ROS) dengan keberadaan antioksidan sehingga kadar radikal bebas lebih tinggi dibandingkan antioksidan. Kelebihan radikal hidroksil dan peroksinitrit dapat menyerang membran sel dan lipoprotein sehingga membentuk peroksida lipid. Reaksi tersebut menghasilkan MDA dan beberapa komponen diena terkonjugasi. Dengan demikian, semakin tinggi kadar MDA berarti semakin besar potensi kerusakan membran sel dan lipoprotein. Kerusakan pada membran sel dan lipoprotein akibat MDA dapat meningkatkan kejadian kanker, penyakit degeneratif, dan aterogenik $(20,21)$. 
Hingga saat ini belum ada informasi yang menyatakan kadar MDA normal dalam tubuh manusia, baik pria maupun wanita. Namun demikian, hasil penelitian di Iran diperoleh bahwa kadar MDA plasma pada wanita sehat usia 20-45 tahun dengan IMT normal (19-25 kg/ $\mathrm{m}^{2}$ ), nilainya kurang dari $1,4 \pm 0,3 \mu \mathrm{mol} / \mathrm{L}$ (22). Dengan demikian, rerata kadar MDA subjek kelompok perlakuan sebelum intervensi dan pada kelompok kontrol sebelum maupun setelah intervensi adalah di atas nilai rata-rata hasil penelitian di Iran tersebut. Kadar MDA subjek yang lebih tinggi tersebut diduga karena kebiasaan subjek dalam mengonsumsi makanan gorengan. Makanan gorengan yang biasa dijual di pasaran umumnya menggunakan minyak yang digunakan secara berulang. Hasil penelitian pada minyak sawit yang dipanaskan berulang menunjukkan terbentuknya radikal bebas yang cukup tinggi (3).

Hasil dalam penelitian ini menunjukkan bahwa pangan intervensi yang dapat menurunkan kadar MDA secara signifikan $(\mathrm{p}<0,05)$ setelah intervensi selama 21 hari adalah minuman cincau hijau dan jus tomat. Hal ini tidak terlepas dari peran antioksidatif senyawa klorofil dan flavonoid yang banyak terdapat pada minuman cincau hijau $(11,12)$. Senyawa turunan klorofil terbukti dapat menghambat peroksidasi lipid pada membran deoxyribonucleic acid (DNA) yang diambil dari sel limfosit manusia (23). Sementara itu, zat antioksidan pada tomat terutama berasal dari senyawa fenolik, likopen, dan karotenoid, serta vitamin C $(14,24)$. Kandungan likopen tomat cenderung mengalami peningkatan selama proses pengolahan dalam pembuatan jus atau pasta tomat (25).

Lebih lanjut, penurunan MDA yang tidak signifikan pada kelompok pepaya dan teh tawar menunjukkan bahwa jumlah pangan antioksidan pepaya ataupun teh per satu takaran saji per hari selama 21 hari masih kurang untuk menangkal pembentukan dan penetralan ROS dalam tubuh. Hasil dalam penelitian ini sejalan dengan penelitian yang mengamati pengaruh pemberian ekstrak pepaya terhadap status oksidatif pada kelinci normal sebanyak $200 \mathrm{mg} / \mathrm{kg}$ berat badan selama 24 minggu, yang menunjukkan bahwa pemberian ekstrak pepaya tidak berpengaruh pada kadar MDA serum (26). Demikian juga halnya dengan teh tawar, penelitian ini sejalan dengan hasil penelitian di University of Medical Sciences, Iran, yang menunjukkan bahwa tikus yang diinduksi nikotin kemudian diintervensi teh hitam tidak menunjukkan penurunan kadar MDA dalam darah (27). Efek antioksidatif teh hitam ini lebih rendah dibandingkan dengan teh hijau. Hasil penelitian sebelumnya menunjukkan terjadinya penurunan MDA sebanyak $10 \%$ pada subjek yang diberi teh hijau selama 12 minggu (28). Hal ini didukung pula oleh penelitian yang menunjukkan bahwa bioavailabilitas dan sifat antioksidatif teh hijau lebih tinggi dibandingkan teh hitam (29).

Reactive oxygen species (ROS) dalam tubuh dapat berasal dari metabolisme sel normal (in situ) dan sumber eksternal (polutan, asap rokok, makanan sumber lipid, paparan sinar ultraviolet, pestisida, olahraga berlebihan, stres, dan lain-lain) (30). Dalam penelitian ini, radikal bebas yang dianalisis diasumsikan merupakan kumulatif dari semua sumber radikal bebas tersebut dan tidak dilakukan analisis tersendiri terhadap masing-masing sumber paparan. Hal ini menjadi kelemahan yang perlu disempurnakan pada penelitian-penelitian selanjutnya sehingga dapat diketahui faktor yang paling berperan dalam pembentukan radikal bebas tubuh selain dari makanan sumber lipid.

\section{SIMPULAN DAN SARAN}

Asupan dan tingkat kecukupan energi serta zat gizi protein, $\mathrm{Ca}, \mathrm{Fe}$, dan vitamin A subjek yang berasal dari makanan tidak menunjukkan perbedaan antarkelompok. Namun, penambahan bahan pangan intervensi menjadikan asupan dan tingkat kecukupan vitamin $\mathrm{C}$ dan vitamin $\mathrm{E}$ berbeda antarkelompok. Tingkat kecukupan energi, protein, $\mathrm{Ca}$, Fe, dan vitamin E sebagian besar subjek adalah defisit dan kurang sedangkan vitamin A dan vitamin $C$ cukup.

Kadar MDA darah subjek penyuka gorengan cenderung tinggi. Pemberian pangan sumber antioksidan minuman cincau hijau secara signifikan memberikan pengaruh dalam menurunkan kadar MDA darah subjek, sebaliknya penurunan kadar MDA darah yang tidak signifikan terjadi pada subjek dengan pemberian jus tomat, pepaya, dan teh tawar. Tim peneliti mengharapkan agar dilakukan penelitian selanjutnya mengenai komponen antioksidan dalam cincau hijau yang berperan dalam menurunkan kadar MDA darah. 


\section{UCAPAN TERIMA KASIH}

Terima kasih diucapkan kepada Direktorat Pendidikan Tinggi (DIKTI) yang telah menopang sebagian dana untuk penelitian ini melalui kegiatan Program Kreativitas Mahasiswa (PKM) bidang penelitian.

\section{RUJUKAN}

1. Nurohmi S, Amalia L. Pengetahuan gizi, aktivitas fisik, dan tingkat kecukupan gizi aktivis Badan Eksekutif Mahasiswa (BEM) IPB. Jurnal Gizi dan Pangan 2012;7(3):151.

2. Zhang Q, Saleh ASM, Chen J, Shen Q. Chemical alterations taken place during deep-fat frying based on certain reaction products: a review. Chemistry and Physics of Lipids 2012;165:662-81.

3. Leong XF, Salimon J, Mustafa MR, Jaarin K. Effect of repeatedly heated palm olein on blood pressure-regulating enzymes activity and lipid peroxidation in rats. Malays $\mathrm{J}$ Med Sci 2012;19(1):20-9.

4. Evuen UF, Apiamu A, Ugbeni OC. Toxicological potentials of repeated frying on antioxidant status of vegetable oils. International Journal of Engineering Research \& Technology 2013;2(3):1-6.

5. Ramatina, Amalia L, Ekayanti I. Pengaruh suplemen antioksidan terhadap kadar malondialdehid plasma mahasiswi IPB. Jurnal Gizi dan Pangan 2014;9(1):35-42.

6. Wahyuni, Asj' ari SR, Sadewa AH. Kajian kemampuan jus buah tomat (Solanum Lycopersicum) dalam menghambat peningkatan kadar malondyaldehide plasma setelah latihan aerobik tipe high impact. Jurnal Kesehatan 2008;2:12332.

7. Bhattacharya S, Gachhui R, Sil PC. Effect of kombucha, a fermented black tea in attenuating oxidative stress, mediated tissue damage in alloxan induced diabetic rats. Food Chem Toxicol 2013;60:328-40.

8. Castell JV, Gmez-Lechn MJ. In vitro methods in pharmaceutical research. London: Academic Pr; 2001.

9. Fatimah AZ, Sartika RAD. Describing fatty acid content in fried foods by using gas chromatography analysis. Agricultural Science Research Journal 2013;3(11):364-9.

10. Wall MM. Ascorbic acid, vitamin A, and mineral composition of banana (Musa sp.) and papaya (Carica papaya) cultivars grown in Hawaii. J Food Comp Anal 2006;19(5):434-45.

11. Nurdin, Kusharto CM, Tanziha I, Januwati M. Kandungan klorofil berbagai jenis daun tanaman dan $\mathrm{Cu}$-turunan klorofil serta karakteristik fisiko-kimianya. Jurnal Gizi dan Pangan 2009;4(1):13-9.

12. Aryudhani N. Mekanisme aktivitas antitumor bubuk daun cincau hijau (Premna oblongifolia Merr.) pada mencit $\mathrm{C}_{3} \mathrm{H}$ yang ditransplantasi sel tumor payudara [Tesis]. Bogor: Institut Pertanian Bogor; 2011.

13. Pinela J, Barros L, Carvalho AM, Ferreira ICFR. Nutritional composition and antioxidant activity of four tomato (Lycopersicon esculentum L.) farmer' varieties in Northeastern Portugal homegardens. Food Chem Toxicol 2012;50(3-4):829-34.

14. Hanson PM, Yang R, Wu J, Chen J, Ledesma D, Tsou SCS. Variation for antioxidant activity and antioxidants in tomato. J Amer Soc Hort Sci 2004;129(5):704-11.

15. Krishna KL, Paridhavi M, Patel JA. Review on nutritional, medical, and pharmacological properties of papaya (Carica papaya Linn.). Nat Prod Radiance 2008;7(4):364-73.

16. Aravind G, Bhowmik D, Duraivel S, Harish G. Traditional and medicinal uses of Carica Papaya. J Med Plants Stud 2013;1(1):7-15.

17. Wurochekke AU, Eze HT, Declan B. Comparative study on the nutritional content of Carica papaya at different ripening stages. Int J Pure Appl Sci Technol 2013;14(2):80-3.

18. Bancirova M. Comparison of the antioxidant capacity and the antimicrobial activity of black and green tea. Food Res Int 2010;43:1379-82.

19. Yao LH, Jiang YM, Caffin N, D'Arcy B, Datta N, Liu X, Singanusong R, Xu Y. Phenolic compounds in tea from Australian supermarkets. Food Chem 2006;96:614-20.

20. Pham-Huy LA, He H, Pham-Huy C. Free radicals, antioxidants in disease and health. Int J Biomed Sci 2008;4(2):89-96.

21. Shalaby EA, Shanab SMM. Antioxidant compounds, assays of determination and mode of action. Afr J Pharm Pharmacol 2013;7(10):528-39.

22. Amirkhizi F, Siassi F, Minaie S, Djalali M, Rahimi A, Chamari M. Is obesity associated with increased plasma lipid peroxidation and oxidative stress in women. ARYA Atherosclerosis Journal 2007;2(4):189-92.

23. Hsu CY, Chao PY, Hu SP, Yang CM. The antioxidant and free radical scavenging activities of chlorophylls and phaeophytins. Food Nutr Sci 2013;4:1-8.

24. Valverde IM, Periago MJ, Provan G, Chesson A. Phenolic compounds, lycopene and antioxidant activity in commercial varieties of tomato (Lycopersicum esculentum). J Sci Food Agric 2002;82:323-300.

25. Alda LM, Gogoasa I, Bordean DM, Gergen I, Alda S, Moldoven C, Nita L. Lycopene content of tomatoes and tomato products. J Agroaliment Proc Technol 2009;15(4):540-2.

26. Omonkhua AA, Onoagbe IO. Effect of irvingia grandifolia, urena iobata, and carica papaya on the oxidative status of normal rabbits. Internet $\mathrm{J}$ Nutr Wellness 2007;6(2). 
27. Joukar S, Shahouzehi B, Najafipour H, Gholamhoseinian A, Joukar F. Ameliorative effect of black tea on nicotine induced cardiovascular pathogenesis in rat. EXCLI Journal 2012;11:309-17.

28. Hidayati AO, Lestariana W, Huriyati E. Efek ekstrak teh hijau (Camellia sinensis (L.) O. Kuntze var. assamica) terhadap berat badan dan kadar malondialdehid wanita overweight. Jurnal Gizi Klinik Indonesia 2012;9(1):41-8.
29. Henning SM, Niu Y, Lee NH, Thames GD, Minutti RR, Wang H, Go VL, Heber D. Bioavailability and antioxidant activity of tea flavanols after consumption of green tea, black tea, or a green tea extract supplement. Am J Clin Nutr 2004;80(6):1558-64.

30. Mena S, Ortega A, Estrela JM. Oxidative stress in environmental-induced carcinogenesis. Mutat Res 2009;674(1-2):36-44. 